\title{
Teaching National Language Based on Local Language: Contrastive Linguistics Approach
}

\author{
Pujiati Suyata $^{1}$, Triwati Rahayu ${ }^{1}$, Roni Sulistiyono ${ }^{1}$ \\ ${ }^{1}$ Ahmad Dahlan University, Jl. Kapas No.9, Semaki, Umbulharjo, Kota Yogyakarta, Daerah \\ Istimewa Yogyakarta 55166, Indonesia
}

\begin{abstract}
This study was aimed at: (1) analyzing of the contrast between the national language and the local language using contrastive linguistics approach (2) facilitating the beginning learner with different local language in learning the national language in order to improve their language mastery. The research model of R\&D was used to identify the similarity and differences of lingual characteristic between the Indonesian as national language and Javanese languages as a local language. The research findings were implemented in Indonesian teaching and learning process aided with the computer-assisted media model based on the learners' mother tongue language. The results indicate the differences between Indonesian language and Javanese language. This result could help the practicing teachers to use local language (LL) in teaching the national language (NL). The computer- assisted media were very helpful for teaching language.
\end{abstract}

\section{Keywords: national language; local language; contrastive linguistics}

\section{INTRODUCTION}

Language plays an important role in human life. As a result of human culture, language develops under a mutually agreed convention. With language, people can communicate, socialize, develop science, and technology for common progress.

Indonesia has a national language, Indonesian language, also known as Bahasa. Bahasa, in accordance with the 1945 Constitution of The Republic of Indonesia has been designated as the national language, the language of the country, and the unity of the Republic of Indonesia. In addition, Indonesian is also defined as the language of instruction at all levels of education [7]. Therefore, Bahasa needs to be mastered well by all learners.

Since Indonesia has hundreds tribes and cultures, each tribe has their own local language. There are hundreds of local languages used in communicating and interacting. The local language is preserved, especially in daily life, traditional ceremonies, and cultural needs. The generations of each tribe also use the local language as their first language, especially in rural areas. In Yogyakarta for example, Javanese language and culture is still used and maintained well. It may also happen in other areas with different local languages.

In accordance with the provisions that exist, for primary learners grade I, teacher should explain all subjects using Bahasa as Indonesian language instruction. It 
can be seen from the first page of Indonesia language lesson book. In chapter 1 with the theme "Diriku (My self)", the learners are provided with the following text:

"Aku dan Teman Baru”, (Me and my new friends)

Kita memiliki teman (We have friends)

Teman membuat kita tersenyum, (that make us smile)

Teman membuat kita tertawa (that make us laugh)

Teman menolong kita (that help us)

Kita belajar bersama teman (We learn many things together)

Kita harus sayang kepada teman (We love each other)

Terima kasih Tuhan, saya memiliki teman. (Thanks God for giving me some friends)

(Buku Tematik Terpadu Kurikulum 2013, Buku Siswa SD/MI Kelas 1, subtema "Aku dan Teman Baru”)

The above conditions make difficulties for learners because they have not been able to read yet, especially for those whose local language as their L1. To overcome this issue, the teacher then explains it in the local language, the language that the learners have mastered. Thus, learners have to study in two stages, first learning the language of instruction, after which they learn the content of teaching materials. Learning becomes ineffective because the teacher has to repeat the explanation using two languages. In fact, reading comprehension becomes important in Curriculum 2013, which is integrative thematic, because Indonesian language literacy is an advocate of other subjects. With a good reading comprehension, learners will more easily absorb the subject matter in school. In reading, reading comprehension engaged the meaning of words, sentences, and texts as a whole. These conditions cannot be allowed to continue, unless the solutions are found [9].

There are several ways to improve the effectiveness of reading comprehension, one of which uses media. Learning media is a mean to convey messages and information subject matter. One of the learning media used in this study was computerassisted learning media. In this case, the learning materials are presented in the form of text, images, graphics, and audio using computer systems. With the media, learning is more interesting and clearer; the teaching becomes more interactive, and time is used more effective. However, it is not known for certain whether the computer-assisted media is effective for primary school learners on local languages learning process. With such great benefits, a study on local language learning process using computer-assisted media needs to be done. 
The problems to be answered in this study were:

1. How is the use of Bahasa in primary school level learning?

2. What is the contrast between Bahasa and Javanese language?

3. How is the design of computer-assisted media, based on the contrasts between Javanese and Indonesian, for primary school learners?

\section{THEORETICAL REVIEW}

The study of contrasting comparisons between Local and National languages, between Javanese language and Bahasa can bridge this difficulty. The beginners are able to use elements of similarities and differences between the two languages in learning Bahasa, as the language of instruction and as a subject.

\section{Bahasa and Javanese Language: Analysis of Language Characteristics}

From the existing linguistic elements, contrastive comparative linguistics studies explain that Bahasa is different from Javanese language, although both are one subgroup, West Malay Polynesian Malay [3,15]. West Polynesian Malay includes Sumatranese, Javanese, Balinese, and Lombok language. Bahasa as West Polynesian is developed from both local (hundreds tribe languages) and foreign languages, such as Sanskrit, Dutch, Portuguese, and English.

The understanding of the characteristics and contrasts between Bahasa and Javanese language helps the primary school learners in classroom learning. Contrasts in both languages can be presented in the form of interesting learning media, namely computer-assisted learning media.

\section{Local Language and National Language}

It has been mentioned that Bahasa as a national language has been defined as the language of instruction in schools at all levels of education, in accordance with the Law on National Education System Article 33 paragraph 2 number 20 of 2003. This provision implies the need for a good mastery of the language by learners, including the beginners of primary school.

However, the Law of National Education System also states " For areas that still find the difficulties in using Bahasa as the medium of instruction, the use the local language is allowed". Thus, the teacher may explain the subject matter with the local language. Nevertheless, it brings the impact of the slow absorption of subjects by the learners. Learning becomes ineffective because the time required is longer than if the teacher explains Bahasa directly. It is necessary to find the solution for those issues.

Beside Bahasa as a national language, Indonesian has hundreds of local languages. Indonesian Language Agency mentions that in 2011 the number of local languages were 746 [13]. The huge number of local languages brings about cultural diversity and customs in Indonesia. The local language is preserved and its existence is protected by the law. This is because regional languages are the entrance to ethnic culture, local wisdom, and traditional noble values that need to be maintained. 


\section{Contrast Between Bahasa and Javanese Language}

One part of comparative linguistics is contractive linguistics. Contractive Linguistic studies the comparisons between languages in the same period. In its development, contrastive linguistic theories that use constructional analysis are used for language learning. Suyata and Suhardi pioneered this study by performing a contrastive analysis between Bahasa and Javanese language. In this case, Bahasa is the second language for speakers whom their L1 is Javanese language. The basic theory of Contrastive Linguistics that concerns on interference and transfer can be used for Bahasa learning process [16].

In addition, the preliminary survey revealed that although Indonesian and Javanese languages are in a single clump, namely the Malay language of Western Polynesia, there are some differences between them [14]. In terms of phonology, for example, the second Indonesian phoneme /a/ will reflex to /e/ in the Javanese language. Example word /asap/ in Bahasa becomes /asep/ in Javanese language; /sambal/ be /sambel/; /arang/ be /areng/; or /lengan/ be /lengen/.

The contrast of both languages also appears at the sentence level. The sentence "Iki bukune sapa?" (Whose book is this?) In Javanese, can be "Ini bukunya siapa?" In Indonesian. In fact, in good and right Indonesian, it will be "Ini buku siapa?" The contrast between the two languages can be used as a basis for learning Indonesian for learners who speak the first language of Javanese. By contrast, learners can learn Indonesian more easily.

Thus, the contrasts between the two languages, in which case the local language and the national language, can be used in Bahasa learning. In this case the local Javanese language can improve the effectiveness of Bahasa learning process, such as research conducted Bachore in Ethiopia. He said, mother tongue plays a role in learning a second language [2]. It is in line with UNESCO that the learners who master the language make the learning effective.

\section{Language Learning Strategy}

The purpose of language learning is improving learners' language mastery, namely speaking, reading, listening, and writing. In terms of reading learning, the strategies used are from theories about how meaning is derived from reading activities. Thus, the purpose of this activity is reading comprehension. There are several theories related to early reading comprehension, one of the theory says that the mastery of vocabulary at the basic level is to know its form and meaning [17].

This issue also applied in bottom up understanding model. This model begins with the smallest element of the language, namely phonemes, words, sentences, to the understanding of the text as a whole. The bottom up model seems appropriate for learners who learn Indonesian as a second language at the early stage [4]. With the theory of contrastive analysis, they learn to recognize the difference between phonemes, words, and the structure of the first and second language sentences unlike the case with advanced learners who need certain reading strategies that emphasize the acquisition of overall meanings, both literary and inferential. Furthermore, it can be done for comprehending of the text as a whole. This strategy is also used in the Thematic Integrated Curriculum 2013 textbook (Ministry of Education and Culture of Indonesia, 2016). 
Writing and speaking are productive aspects of language learning. Although both are productive aspects, both have significant differences. The competencies that must be possessed by learners in writing are different from the competencies required to speak. Writing is done by affixing graphic symbols that describe the language. Thus, learning to write at the beginner level is to affix and arrange the letters. In this case, affix letters begins with writing preparations that include sitting, pencil-holding, and eye-sight (Thematic Integrated Curriculum 2013). Once everything is done, then it starts by following and tracing the letters.

\section{Language Learning Media}

In understanding the text, it takes good vocabulary mastery [12]. The higher the mastery of vocabulary, the more likely it is for learners to understand the text they read. This is true, especially for beginner reading learners. In addition, the readiness of the novice readers is also supported by appropriate learning media. Learning media is a means of teaching messengers. With the media, learning will be more lively and learning messages will be delivered thoroughly [5]. The media itself can be divided into printed media and unprinted media (modern technology-based media).

The existence of reading media contains a number of benefits, such as learning process becomes more interesting, interactive, and effective. Thus, with an interesting medium, learners' passive attitudes can be minimized because they are actively involved in learning. Learning becomes interesting and not boring.

\section{Computer-assisted Learning Media}

Computer-assisted media is a learning tool that utilizes computer systems to deliver direct messages to the learners. Computers can be used in teaching and learning [6]. All learning materials can be presented with the assistance of computer technology [8]. In computer-assisted media, there can be various elements, such as text, graphics, audio, images, motion, and colour. In addition, the development of technology-based media is proven to provide concrete national language learning in Cameroon [11].

There are several criteria that need to be considered in the selection of computer media, that is accuracy with the purpose of learning, support the content of learning materials, the ease of obtaining media, the skills of teachers in using it, and conformity with the learners' comprehension. In addition, the media should be artistic and interesting to the learners.

In terms of quality, computer-assisted learning media needs to meet several criteria, both in terms of material content, programming design, and display aspects. From the aspect of the material content: definite competency objectives, the content of knowledge, skills, and attitudes are suitable with the unit, the language is easy to understand, tasks and exercises are available, the tasks are suitable with the competency unit, and assessment instructions are easy to understand. Media criteria in terms of software design. These criteria are related to introduction, learner control, presentation of information, providing help, and ending a program [1]. The software should be userfriendly and can be delivered in various ways [10].

There are various models of computer-assisted media, one of which is Macromedia Flash. In this media, learning materials are included in the flash, and teachers teach the material using computers and LCD. This model looks practical and 
can be done in schools including primary school classes. Another model is the Androidassisted media. In this model, the subject matter is packaged in mobile phone, then learners learn independently with mobile phone. The Android model does not seem to be suitable for primary school learners because the teacher has not allowed learners to use their own.

\section{Local Language-based Macromedia Flash in National Language Learning}

National language reading competence, in this case Bahasa, is an urgent competency in its capacity as an advocate of Bahasa subjects and other subjects. This is revealed in the Curriculum 2013 which emphasizes text-based learning. Related to this, one way to realize the success of text-based learning is by developing the learning media based on macromedia flash. The media compiled with certain requirements, namely interesting, intriguing interest, easy to use, and clear instructions.

Macromedia flash media can be arranged in a local language-based, especially for early-grade primary learners whose L1 is local language. The results of contrastive analysis of local languages and national languages can be used for that issue. Bottom-up modelling strategies can be used for primary school classes. In this case, macromedia flash learning used in Javanese based Bahasa learning for primary school in DIY.

Integrated Thematic Theme Curriculum 2013, for primary school has 4 themes, namely Theme 1: "Diriku (My Self)", Theme 2: "Kegemaranku (My Hobby)", Theme 3: "Kegiatanku (My Daily Activities)", and Theme 4: "Keluargaku (My Family)". Teaching learning process is done based on Core Competence (CC) and Basic Competence (BC) that has been determined. Based on $\mathrm{CC}$ and $\mathrm{BC}$ theme, each theme consists of 4 subthemes, and each subtheme is taught for 6 days. Thus, each theme is taught within 24 days or 1 month. For the whole, which is 4 themes, it takes 4 months.

Macromedia flash developed in this study is compiled with different specifications, and referring to Curriculum 2013 with those themes. The media are packed in 6 meetings and concludes with a competency test, intended as a "Curriculum 2013 Supplement”.

\section{RESEARCH METHOD}

The method used in this research was Research \& Development (R\&D). The steps taken were (1) need analysis on learning condition of Indonesian primary school in Yogyakarta Province, (2) review analysis about contrastive language comparison theories forwarded survey related to contrastive identification of Bahasa and Javanese language. (3) literature review followed by preparation of media design "Bahasa Learning Media for primary learners based on Macromedia Flash: Supplements for Curriculum 2013". (4) Focus Group Discussion (FGD) on Macromedia Flash media design that had been prepared. FGDs were performed by the experts and users. The experts consisted of macromedia flash media experts, learning experts, and learning material experts. The users were supervisors, principals, and grade I primary school teachers.

The instruments used were (1) questionnaires and observation guidelines for need assessment survey (2) a list of 500 Bahasa vocabularies arranged in the form of "network system" translated into the Javanese language. The informants of 27 people in criteria: consisting of men and women; aged 40-60 years; lived in the area for two 
generations; primary-junior high school education; job: farmer/selfemployed/housewife; complete speech; and rarely travelled to outside area. (3) open questionnaires and observation guidelines for FGD results data. Data were analyzed in descriptive qualitative and quantitative. The research location was (1) SD Negeri Kalidadap, Imogiri, Bantul, (2) SD Negeri Wiloso, Panggang, Gunungkidul, and (3) SD Negeri Rejosari, Tanjungsari, Gunungkidul, and (4) Ahmad Dahlan University Campus.

\section{FINDINGS AND DISCUSSION}

\section{Findings}

The survey results explain that Bahasa was only occasionally used by the teacher in learning process. Learners had not been able to comprehend well the Indonesian language which teachers use. Teachers must repeat the lesson using Javanese language. As a result, learning was not effective, the absorption of subjects was hampered, and learning was not maximal.

A survey of contrast between Javanese language and Bahasa obtained (1) The second Indonesian phoneme /a/ syllabi became /e/ weak in the Javanese language. (2) The phoneme h- the initial position of Bahasa is lost (zero) in the Javanese language. (3) Phoneme /b/ in Bahasa turns into /w/ or /b/. (4) Phoneme /ai/ turns into /e/. (5) The phoneme /au/ turns into /o/ (6) The initial phoneme /e/ turn into 0(zero) (7) Indonesian and Javanese as part of the Western Austronesian language family follow the RGH Law. And (8) Indonesian and Javanese as a family of Malay Polynesian West follow the RDL Law.

FGD results on macromedia flesh media design for Bahasa learning for learner school are as follows. In general, the draft is well prepared and acceptable. However, some revision are required, the image of cats and buffaloes need to be differentiated in size, buffalo heads and goats need striking differences, in order to use terms that are easily known to learners, "jajan (snacks)" replaced "kue atau roti (cakes or breads)", for example. Media experts argue that the prepared media is good enough, music and interlude songs are accepted. Macromedia flash is more suitable for primary learners than Android-based media because primary learners are not allowed to bring a mobile phone to school. The materials expert believes that the material is appropriate to the beginning primary school level, while the teaching expert informs that the media is organized and seems to be applicable in the school. The supervisors, teachers, and principals' opinions are generally similar, that is a well-crafted design that seems to work in the classroom. Thus, it can be said that the design of media macromedia flash compiled has been validated by media experts, material experts, learning experts, users, teachers, principals, and school supervisors.

\section{Discussion}

The need assessment survey results explain that Bahasa is only occasionally used by teachers in learning. Learners have not been able to understand well the Indonesian language teachers use. Teachers must repeat the lesson using Javanese language. It is understandable considering the learners' everyday language is the 
Javanese language. Teachers argue that the use of Javanese language is aimed to maintain the existence of the language which is a wealth of Yogyakarta local language.

It is understandable, but related to learning as a whole, it inhibits the absorption of learning materials in its entirety. Learning becomes ineffective. These conditions need to find solutions, including the use of Javanese-based learning media in teaching Bahasa. By using computer-based interesting media, sounds, pictures, colors of fun are presented. The learning is also getting easier and faster.

The findings on the contrastive study between Bahasa and Javanese Language obtained the result that the two languages have differences even though they are in a single language, namely West Polynesian Malay. Based on the contrastive characteristics of the two languages, the learning media can be designed. The media is considered appropriate for beginner learners whose L1 Javanese language. By following the contrast in both languages, the learners more easily learn L2, which in this case is Bahasa using these media. This is in line with the purpose of Contrastive Comparative Linguistics, one of which is for language learning. Sound reflexes that occur in contrast between the two languages, occur regularly and it becomes useful for language learning.

This research is at the phonemic level. However, it can actually develop also to other levels such as words, word groups, or sentences. There is a contrast between the Javanese and Bahasa sentences. For example, in Javanese: "Iki bukune sapa?" (Whose book is this?) People often say it in Bahasa, "Ini bukunya siapa?" The element "nya" in the Bahasa is wrong, because it is the construction of Javanese language.

Associated with computer-assisted media, there is the possibility of school facilities, such as electrical capacity, computers, and LCDs become obstacles in the implementation. In the province of Yogyakarta it may not happen, but it maight be happen to the rural schools which have limited learning facilities.

FGD results on macromedia flash media design for Bahasa learning in primary level are generally good and acceptable. However, some revisions are required, regarding to the size of the image, the color of the letter, and the terms used. Media experts argue that macromedia flash-based media is more suitable for primary learners than Android-based media. This is understandable since primary learners are not allowed to bring mobile phones to school. Material and Learning experts have similar opinion toward that issue, the media is appropriate for primary school learners. This is also in line with the opinion of supervisors, teachers, and principals. i.e., a well-crafted design that is expected to be applied in the classroom. Thus, the design of learning media based on macromedia flash for primary level SD is feasible.

\section{CONCLUSION}

After following the above description, it can be concluded as follows. First, Bahasa has not been fully utilized in early grade learning. Bahasa is used only occasionally because learners cannot understand Indonesian well enough. As the result, the absorption of learning is hampered and learning outcomes are not maximal. Second, Bahasa and Javanese Language are in one language group, West Malay Polynesian Malay. There are many similarities between the two languages, but there are also differences. The contrasts that exist primary between the two languages include several things, which this study focuses more at the phonemic level. The contrasts between the two languages can be used for beginners in learning Bahasa using their L1, Javanese 
Language. Third, the design of macromedia flash media for learning Bahasa in primary level has been validated by the experts as well as the users. Thus, the draft can be followed up to be the real media.

\section{REFERENCES}

[1] Alessi, Stephen M and Stanley R. T. 2001. Multimedia for Learning: Methods and Development (3rd Edition). MA: Allyn \& Bacon, Inc.

[2] Bachore, Mebratu Mulatu.. 2014. "The Role of Mother Tongue Based Education in Ensuring the Quality of Classroom Instruction: Opportunities and Challenges". Journal of Education and Literature. 1(1): 31-38.

[3] Bellwood, Peter. 1995. Austronesian prehistory in Southeast Asia: homeland,expansion and transformation. In The Austronesians: historical and comparative perspectives. Peter Bellwood, James J. Fox, and Darrell Tryon, eds. Canberra: Australian National University. pp. 103-118

[4] Brown, H. Douglas. 2007. Teaching by Principles: An Interactive Approach to Language Pedagogy. San Fransisco: Addison Wesley Longman, Inc.

[5] Chun, D., Richard Ken, Bryan Smith. 2016. "Technology in Language Use, Language Teaching, and Language Learning”. The Modern Language Journal. 100(S1): 64-80.

[6] Cilesiz, Subnem. 2009. "Educational Computer Use in Leisure Contex: A Phonological Study of Adolelescents' Experience at Internet Cafes". American Educational Research Journal, 46(1) : 232-274.

[7] Depdiknas. 2003. Undang-Undang Sisdiknas. Jakarta: Depdiknas.

[8] Egbert, Joy.L. and G.M. Petrie. 2005. Call Research Perspective. Mahwah: Lawrence Erlbaum Associates,Inc

[9] Linse, C. T. \&Nunan, D. (Ed). 2005. Practical English Language Teaching: Young Learners. New York: McGrawHill

[10] Mishra, S and R.C. Sharma. 2005. Interactive Mutimedia in Education and Training. Calgary: Idea Group Publishing.

[11] Nkenlifack, M., B. Demsong, A.T. Domche, and R. Nangue. 2011. "An Approach for Teaching of National Languages and Cultures through ICT in Cameroon". (IJACSA) International Journal of Advanced Computer Science and Applications. 2(7):1-10.

[12] Richards, J.C. and W.A. Renandya. 2002. Methodology in Language Teaching: An Anthology of Current Practise. Cambridege: Cambridge University Press.

[13] Sudaryanto. 2014. "Studi Tentang Perkembangan Bahasa Indonesia Di Tiongkok Dan Dampak Kesarjanaan Tiongkok Bagi Pengajaran Bahasa Indonesia”.Kajian Linguistik dan Sastra. 26(1): 61-70.

[14] Sulistiyono, R., P. Suyata, T.Rahayu. 2017. "Contrastive Analysis of Indonesian and Javanese Languages and Its Prospective Implication for Language Learning" presented at 17th YICEMAP, May 13, 2017.

[15] Suyata, P. 2007. Studi bahasa dan budaya Austronesia di Indonesia dalam perspektif integritas bangsa dalam Kearifan Sang Profesor. Yogyakarta: UNY Press.

[16] Suyata, P. and Suhardi. 2009. Analisis Kontrastif Bahasa Indonesia-Daerah dan Implikasinya Dalam Pembelajaran Bahasa Kedua: Model Multikulturalisme Dalam Pembelajaran Bahasa Yogyakarta:LPPM UNY.

[17] Thombury. S. 2002. How to Teach Vocabulary. Harlow: Pearson Education Limited. 